\title{
GENERAL REVIEW OF THE SURVEY'S ACTIVITIES IN 1969
}

The Geological Survey of Greenland continued in 1969 to carry out its three main tasks - the geological mapping of Greenland, the investigation of mineral deposits of economic interest and the publication of results. In addition the Survey has acted as geological adviser to the Ministry for Greenland in matters concerning the granting of mineral exploration concessions.

Geological mapping

Three categories of geological maps are published by the Survey:

1) Regional maps at scales $1: 500000$ and $1: 2500000$

2) Survey map sheets at scale 1:100 000

3) Detailed maps of selected areas

Regional maps

A five-year programme for the preparation of regional geological maps of West Greenland at $1: 500000$ was begun in 1964. The preparatory field work was completed in 1969. It is planned to cover the whole of West Greenland in four sheets and these will be published in the following years at the rate of one a year.

A new geological map of Greenland at 1:2500 000 is in proof and will be published early in 1970.

A new Quaternary map of Greenland at 1:2 500 000, which has been planned as a supplement to the geological map at the same scale, has been delivered to the printers and will be published in 1970 or early in 1971 . The Survey is also collaborating in the production of a metallogenic map of North America which will include Greenland.

Survey sheets at 1:100 000

Map sheets at 1:100 000 are the main repository for the results of field mapping in Greenland. The map sheets Mârmorilik and Nûgâtsiaq were in proof at the time of writing.

Economic-geological investigations

The Survey has assisted several private companies that have exploration concessions in Greenland. The companies have been provided with maps and information from 


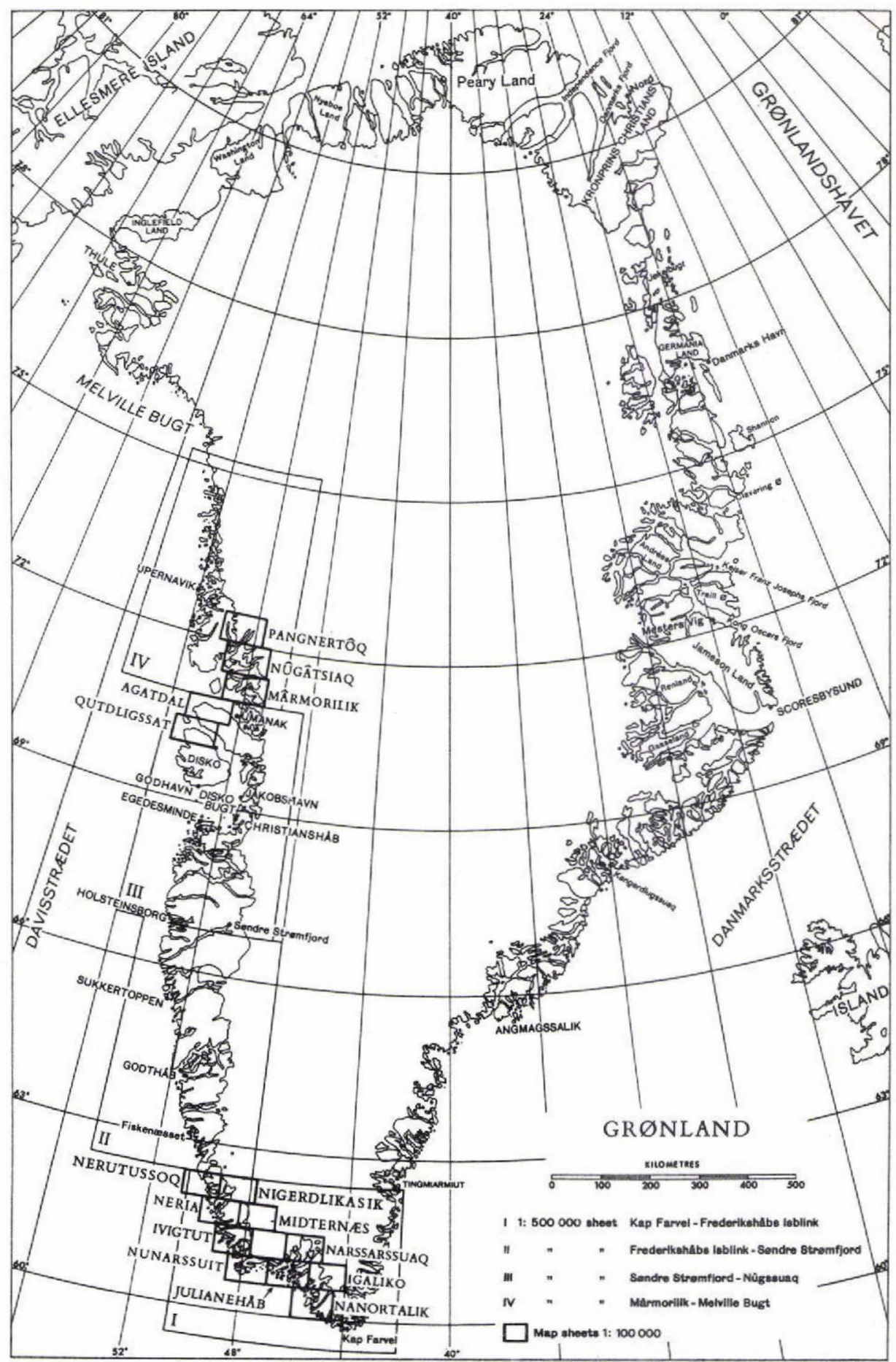

Fig. 1. 
areas in which they are working. The Survey has also corresponded with a large number of foreign companies concerning economic possibilities in Greenland. As a result of these efforts 8 new concessions were granted in 1969 by the Ministry for Greenland and the total number of companies operating in Greenland is now 22.

The Survey has continued routine studies of various potential mineral resources, e. g. uranium, thorium and zirconium in the Ilimaussaq intrusion near Narssaq. This work is carried out in close cooperation with the Atomic Energy Commission's Research Establishment at Risø. A report on the bituminous shales of Nûgssuaq and their geological setting has been published and more than 200 oil companies reacted and asked for further information.

Apart from these special studies records of mineralisations have been kept in the course of the regional field mapping, and companies holding concessions have been supplied with metallogenic observations.

The Director of the Survey, as government representative in the Board of Nordisk Mineselskab A/S, has contributed to the planning of the prospecting activity of this company.

\section{Expeditions}

In all 117 persons participated in the Survey's activity in 1969. The biggest group operated in the Scoresby Sund area, East Greenland. This group consisted of 15 two-man geological parties and the whole operation was based on $\mathrm{m} / \mathrm{s}$ "Magga Dan". The parties were supported by two helicopters which operated from the ship's two heliplatforms. The weather in this part of Greenland was extremely bad in 1969, but in spite of this the expedition managed to fulfil its programme satisfactorily.

The main activity in West Greenland was in the area south of Søndre Strømfjord, and the expedition here was based in a barrack which was put at the Survey's disposal through the kindness of the United States Air Force, Sondrestrom Air Base. This expedition succeeded in mapping a large hitherto unknown area at 1:250000.

A special group moved one of the Survey's base camps to a new site near Fiskenæsset and prepared the coming years' field activity between Frederikshåb Isblink and Godthåb.

As a supplement to the geological work a geophysical survey was carried out on Nûgssuaq peninsula in order to obtain more information on the thickness of the sedimentary succession.

The study of permafrost in West Greenland was continued. In Holsteinsborg and Godhavn an attempt was made to measure the depth to the permafrost table by using geoelectric methods.

In South Greenland a study of ore minerals in Sanerutian (late Ketilidian) basic intrusions was started. Special attention was paid to layered hornblende peridotite intrusions.

Aerial photography was carried out in both East and West Greenland in 1968 by the Geodetic Institute in collaboration with the Survey. This work was not finished 
and the Survey continued the work in 1969 with an air charter company which carried out aerial photography in the Scoresby Sund area as well as in the Fiskenæsset region, where the Survey's activities will be concentrated in the coming years.

\section{Collaboration with other institutes}

The Survey has continued to maintain a close contact with a large number of other institutes, both Danish and foreign, in order to benefit from the sharing of resources and the exchange of ideas. In keeping with this policy the Survey has in the past year collaborated with the Mineralogical-Geological Institutes and Mineralogical Museum of the University of Copenhagen, the Danish Atomic Energy Commission, the Geological Institute of the University of Aarhus and the Mineralogical Institute of the Technical University in Copenhagen. Furthermore the Survey field team was joined in 1969 by geologists from the universities of Bern, Basel, Zürich, Durham, Liverpool, Edinburgh, Exeter, Lausanne and Seattle.

A geologist of the Scottish Research Reactor Centre joined a field party in South Greenland and collected material from pre-Ketilidian and Ketilidian granites and gneisses for $\mathrm{Rb}-\mathrm{Sr}$ and zircon age dating.

One member of the Survey joined the excursions in Sweden and Finland organised in conjunction with the IUGS Subcommission on Precambrian Stratigraphy meeting in Stockholm in June 1969, and later joined a Geological Survey of Canada field operation in Labrador led by Dr F. C. Taylor. Considerable progress was made in providing a factual basis for correlation of the main geological units on each side of the Davis Strait.

Another geologist participated on behalf of the Survey in the British Joint Services Expedition to North Peary Land led by Major J. D. C. Peacock R. E. M. E.

Much of the work in Greenland forms not only part of the survey mapping programme but also a contribution to various international research projects. Work has continued on projects forming part of the Danish programme for the International Upper Mantle Project and UNESCO's International Hydrological Decade.

\section{Organisation and personnel}

The permanent scientific staff of the Survey in 1969 consisted of 16 geologists and 1 chemist. During the field season this team was supplemented by 26 geologists from other institutes (see above) and 22 senior students. The permanent supporting staff in Copenhagen numbers 26; this figure is relatively low due to the sharing of many facilities with the Mineralogical-Geological Institutes and Mineralogical Museum. The total number of participants (geologists and supporting staff) in the summer expeditions was 117 together with 30 Greenlanders.

For many years it has not been possible to increase the permanent scientific staff in keeping with the greatly increased expedition activity and burden of administrative work. This situation was due to space limitations in the institute and financial limitations resulting from budgetary cuts imposed by the government. In 1969 conditions 
in the institute were improved when the Survey moved to a building in Østervoldgade 10. It has nevertheless been necessary to redistribute the efforts of the Survey by reducing field activity so that smaller expeditions will be sent to Greenland in the coming years. This reduction will benefit the home-based activities in Copenhagen, where greater efforts will be made to publish results and accelerate publication procedure, as the quick, efficient release of information is regarded as of great importance.

New fields of scientific investigation, where the Survey has not previously been active, were discussed in 1969. There is a growing interest in the bedrock geology under the Inland Ice as well as the off-shore areas along the coasts. The significance of new geochemical techniques for future work has also been taken into account in planning.

Finally it should be mentioned that practical arrangements to meet the rapid increase in the pressure of work which already has been felt, and can be expected to continue, as a result of the passing of the act on mineral resources, have been under consideration.

K. Ellitsgaard-Rasmussen Director

\title{
GEOLOGICAL INVESTIGATIONS IN NORTHERN PEARY LAND
}

\author{
Peter R. Dawes and N. J. Soper
}

\section{Introduction}

The authors were in North Greenland from the end of April to the beginning of September as members of the British Joint Services Expedition led by Major J. D. C. Peacock R. E. M. E. During this time reconnaissance investigations were carried out in northern Peary Land in an area about $8500 \mathrm{~km}^{2}$. Travel until mid-June was by sledge on the sea-ice, thereafter by ski and on foot in the Roosevelt Fjelde. Resupply was by parachute drops made by an RAF C-130 Hercules aircraft.

The work carried out was within the folded zone of the North Greenland Fold Belt. An attempt was made to collect enough data in the area north of Frederick E. Hyde Fjord and west to Lockwood $\varnothing$ for a geological map on the scale 1:250 000 to supplement the limited information that is available from the folded rocks of Peary Land (Koch, 1920, 1923a, 1923b, 1925; Ellitsgaard-Rasmussen, 1955; Fränkl, 1955). 